\title{
Influence of the watering time on growth and solid feed intake of rabbits submitted to a restriction in the duration of water availability
}

\author{
Y. CARLES et M. PRUD'HON \\ Laboratoive de la chaire de zootechnie \\ E.N.S.A., Place Viala, 37060 Montpellier Cedex (France)
}

\begin{abstract}
Rabbits submitted to a restriction in the daily duration watering also limited their feed intake after a more or less long period of adaptation.

Two experiments made on 80 and 48 growing New Zealand white rabbits respectively (from $75^{\circ}$ or $\mathrm{I} 000 \mathrm{~g}$ to $2400 \mathrm{~g}$ ) were realized the with purpose of studying :

- The influence of the watering time on the solid feed intake and growth.

- The adaptative ability of the rabbits to a water restriction.
\end{abstract}

Whatever the time of watering $(9 \mathrm{a} . \mathrm{m}, 9 \mathrm{p} . \mathrm{m}$. or $9 \mathrm{a} . \mathrm{m} .+9$ p.m.) the feed intake level and growth rate of the rabbits submitted to water restriction were reduced as compared to the controls watered ad libitum :

-... The adaptation to a water restriction was easier when the supply was at 9 a.m. rather than at 9 p.m. and in the rabbits of $75^{\circ} \mathrm{g}$ rather than in those of $\mathrm{I}$ ooo g.

- The supplying of water twice a day ( $9 \mathrm{a} . \mathrm{m}$. and $9 \mathrm{p} . \mathrm{m}$.) did not improve either the growth or the feed intake as compared to a single supply at 9 a.m.

The feed conversion ratio was similar in rabbits watered ad libitum or at 9 a.m.; it was increased in rabbits watered at $9 \mathrm{p} . \mathrm{m}$. and in those subjected to a late adaptation.

\section{Chemical composition of crossbred young 35 days old rabbits nitrogen and minerals}

\author{
R. HENAFF, C. MAIRE( $\left({ }^{1}\right)$ et G. PERRIER $\left({ }^{2}\right)$
}

(hatire de zootechnie, E.N.F.A. de Clermont-Ferrand, 63370 Lempdes (France)

(1) Lts Sanders, Laboratoire, I7, quai de l'industrie, $9120 I$ Athis-Mons Cedex (Lrvance)

(2) Chaire de production animale, E.N.I.T.A. de Dijon, 21800 Quetigny (France)

The chemical composition of a strain of crossbred rabbits (white New Zealand $\times$ Californian $x$ small Russian $x$ meat line) was determined on 50 rabbits of 35 days.

The mean live weight was $789 \pm 82 \mathrm{~g}$ and the dry matter content of the animal without digesta was 3 I. $7 \pm 2.5$ p. roo.

Within the total dry matter of the body, the crude proteins represented $70.2 \mathrm{p}$, Ioo with a coefficient of variation (CV) of 2.I p. roo. Calcium and phosphorus represented 4.4 and 2.7 p. Ioo, respectively of the dry matter with coefficients of variation of $\mathrm{I} 6$ and $\mathrm{I} 4 \mathrm{p}$. 100 .

$\mathrm{Mg}, \mathrm{Na}, \mathrm{K}$ and $\mathrm{Cl}$ contents as compared to dry matter were $0 . \mathrm{I} 4$ ( $\mathrm{CV}: 6 \mathrm{p}$. I0o), 0.44 (CV: 2 p. I00), 0.97 (CV : 3 p. IO0) and 0.50 p. I 00 (CV: 2 p. IOO), respectively.

The authors, underline the large homogeneity of their results except for $\mathrm{Ca}$ and $\mathrm{P}$ contents. 